\title{
Influence of Fly Ash on Strength Development of Concrete and its Temperature Dependence
}

\author{
Hiromi Yanokura ${ }^{1}$, Isao Kurashige ${ }^{2}$, Naoyuki Sugihashi ${ }^{1}$, Keiichi Takahashi ${ }^{3}$ and \\ Yasuhiro Kuroda ${ }^{3}$ \\ ${ }^{1}$ Shimizu Corporation, Civil Engineering Technology Division, No.16-1, Kyobashi 2-chome, Chuo- \\ ku, Tokyo, 104-8370, Japan, h-yanokura@shimz.co.jp, n-sugihashi@shimz.co.jp \\ ${ }^{2}$ Central Research Institute of Electric Power Industry, Civil Engineering Research Laboratory, 1646 \\ Abiko, Abiko-shi, Chiba, 270-1194, Japan, kurasige@criepi.denken.or.jp \\ ${ }^{3}$ Shimizu Corporation, Research Institute, No.4-17, Etchujima 3-chome, Koto-ku, Tokyo, 135-8530, \\ Japan, keichi.takahashi@shimz.co.jp,y.kuroda@shimz.co.jp
}

\begin{abstract}
Experiments on the development of compressive strength and static and dynamic Young's moduli were performed by the following mix proportions of concrete: the first uses different types of Portland cement without fly ash (FA) with a water-cement ratio of $45 \%$, keeping at different curing temperatures; the second partially use FA in place of the cement, with the other conditions same as above; the third uses only blast furnace cement B instead of Portland cement. With these specimens, we comparatively examined in terms of temperature adjusted concrete age, how the mechanical properties change with the use of cement only, FA replacement for cement and with variation in curing temperatures. As a result, it was confirmed that the replacement of cement by fly ash enhanced the long-term mechanical properties of concrete regardless of the curing temperature applied in this experiment.
\end{abstract}

Keywords: Fly Ash, Curing Temperature, Compressive Strength, Static Young's Modulus, Dynamic Young's Modulus.

\section{Introduction}

Recently, in Japan, fly ash (FA) has been often used as a mineral admixture of concrete from the viewpoint of effective use of industrial waste and reduction of carbon dioxide $\left(\mathrm{CO}_{2}\right)$ emissions. (Takafumi, 2014) The use of FA as an admixture in concrete is said to be effective in improving concrete performance such as increasing workability of concrete, reducing thermal cracks, development of long-term strength, and suppressing salt damage and alkalisilica reaction. For this reason, in overseas countries, in particular in Asian countries, the trend of effective utilization of FA for concrete has become active due to the increasing number of coal power plants, because FA can be obtained at low cost as industrial waste. The pozzolanic reaction peculiar to FA is activated beneficially to develop the strength of concrete as the curing temperature increases. On the contrary, when the curing temperature is low, the strength enhancement due to the pozzolanic reaction does not progress and, in some cases, the expected effect may not be obtained.

Therefore, in order to understand the temperature dependency of the mechanical properties of the concretes using FA, three kinds of Portland cements which are partially replaced with FA were comparatively studied in terms of the impact by temperature on the development of 
mechanical properties of concrete. Note that we obtained basic data on the mechanical properties of cement types and curing temperatures in order to make full use of the effect of fly ash used in place of cement.

\section{Experiment Plan}

\subsection{Outline of the Experiment}

Regarding the use of cements and FA, one case is that different mix proportions for concrete are prepared at curing temperatures of $5,10,20$, and $30^{\circ} \mathrm{C}$, using only normal Portland cement $(\mathrm{N})$, moderate heat Portland cement (M), or low heat Portland cement (L) respectively with no $\mathrm{FA}$, and another case is that the mix proportions are prepared in the same condition as above, except $30 \%$ of the proportion of the cement was substituted by FA. The specimens of concrete prepared were tested to obtain the strength development (for the case of $\mathrm{N}, 15 \%$ substitution of FA was also applied). For comparison, a mix proportion using blast furnace cement B instead of cement was used in the experiment.

\subsection{Materials and Mix Proportions}

Table 1 shows the list of materials used, Table 2 the quality of FA, and Table 3 the mix proportions (blending). The FA used is JIS A 6201 FA II class product from Noshiro Thermal Power Plant, and water to binder ratio (W/B) is set to be constant at 45\%. Limestone fine

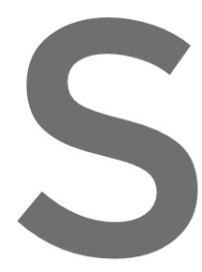
pow der (LP) was used to stablize the fresh properties of mix
FA replacement ratio of $30 \%$.
Concrete mixing was carried out in an environment of 20
forced mixing mixer with a nominal capacity of 100 liters. Th
the concrete is mixed up was $18.0 \pm 2.5 \mathrm{~cm}$, the target air

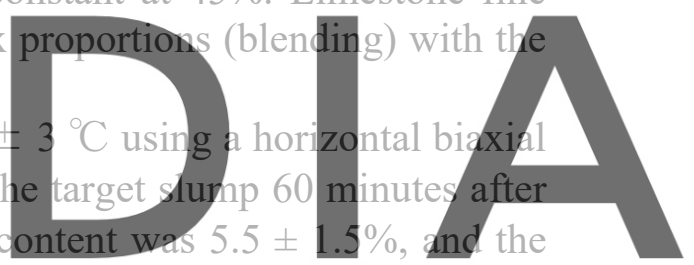
rates of air-entraining water reducing agent (AD) and air-entraining agent (AE) were

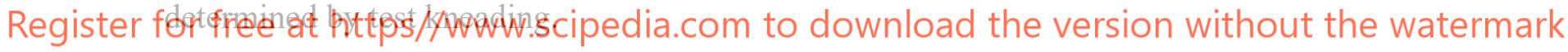

Table 1 . List of materials used.

\begin{tabular}{|c|c|l|}
\hline Material & Symbol & \multicolumn{1}{|c|}{ Name and quality } \\
\hline \multirow{2}{*}{ Binder } & $\mathrm{N}$ & $\begin{array}{l}\text { Normal Portland cement } \\
\text { Density } 3.16 \mathrm{~g} / \mathrm{cm}^{3}\end{array}$ \\
\cline { 2 - 3 } & $\mathrm{M}$ & $\begin{array}{l}\text { Moderate heat Portland cement } \\
\text { Density } 3.21 \mathrm{~g} / \mathrm{cm}^{3}\end{array}$ \\
\cline { 2 - 3 } & $\mathrm{L}$ & $\begin{array}{l}\text { Low heat Portland cement } \\
\text { Density } 3.22 \mathrm{~g} / \mathrm{cm}^{3}\end{array}$ \\
\cline { 2 - 3 } & $\mathrm{BB}$ & $\begin{array}{l}\text { Blast furnace cement B } \\
\text { Density } 3.04 \mathrm{~g} / \mathrm{cm}^{3}\end{array}$ \\
\hline \multirow{2}{*}{$\begin{array}{c}\text { Mineral } \\
\text { admixture }\end{array}$} & $\mathrm{FA}$ & Fly ash Density $2.19 \mathrm{~g} / \mathrm{cm}^{3}$ \\
\hline \multirow{2}{*}{$\begin{array}{c}\text { Fine } \\
\text { aggregate }\end{array}$} & $\mathrm{S}$ & $\begin{array}{l}\text { Limestone fine powder } \\
\text { Density } 2.70 \mathrm{~g} / \mathrm{cm}^{3}\end{array}$ \\
\hline $\begin{array}{c}\text { Coarse } \\
\text { aggregate }\end{array}$ & $\mathrm{G}$ & $\begin{array}{l}\text { Limestone crushed sand } \\
\text { Surface dry condition density } 2.67 \mathrm{~g} / \mathrm{cm}^{3}\end{array}$ \\
\hline $\begin{array}{c}\text { Chemical } \\
\text { admixture }\end{array}$ & $\mathrm{AD}$ & $\begin{array}{l}\text { Limestone crushed stone } \\
\text { Surface dry condition density } 2.70 \mathrm{~g} / \mathrm{cm}^{3}\end{array}$ \\
\cline { 2 - 3 } AE water reducing agent \\
\hline
\end{tabular}

Table 2. Quality data of FA.

\begin{tabular}{|c|c|c|}
\hline \multicolumn{2}{|c|}{$\begin{array}{ll}\text { Test item } \\
\end{array}$} & Test result \\
\hline \multicolumn{2}{|c|}{ Silicon dioxide $(\%)$} & 66.6 \\
\hline \multicolumn{2}{|c|}{ Moisture (\%) } & 0.1 \\
\hline \multicolumn{2}{|c|}{ Ignition loss $(\%)$} & 2.0 \\
\hline \multicolumn{2}{|c|}{ Density $\left(\mathrm{g} / \mathrm{cm}^{3}\right)$} & 2.19 \\
\hline Fineness & $\begin{array}{l}\text { Specific surface area by Blaine } \\
\text { method }\left(\mathrm{cm}^{2} / \mathrm{g}\right)\end{array}$ & 3,880 \\
\hline \multicolumn{2}{|c|}{ Flow value ratio } & 104 \\
\hline \multirow{2}{*}{$\begin{array}{l}\text { Activity } \\
\text { index } \\
(\%)\end{array}$} & Concrete age 28 days & 86 \\
\hline & Concrete age 91 days & 100 \\
\hline
\end{tabular}




\subsection{Test Items and Methods}

Test items and test methods are shown in Table 4. Specimens were taken after confirming that the slump and air content satisfied the target values at a test of fresh concrete 60 minutes after the mixing. After curing 24 hours in an initial curing room at a temperature of $20 \pm 2{ }^{\circ} \mathrm{C}$ with a relative humidity of $95 \%$ or more, the specimens were removed from their forms to be cured in the water at specified temperature conditions until specified ages when the specimens were subjected to various tests.

\section{Test Results and Discussions}

\subsection{Test Results of Fresh Concrete}

Table 5 shows the test results of fresh concrete. At every mix proportion, the slump and air content after 60 minutes met the targets. Remarkably, the mix proportion with $30 \%$ FA replacement, despite the high use of $\mathrm{AE}$ agent, recorded a more than $0.5 \%$ decrease in air content presumably due to unburned carbon of FA. In particular, the mix of LF30 had an extremely high decrease of $2.4 \%$ in air content.

Table 3. Mix proportion of concrete.

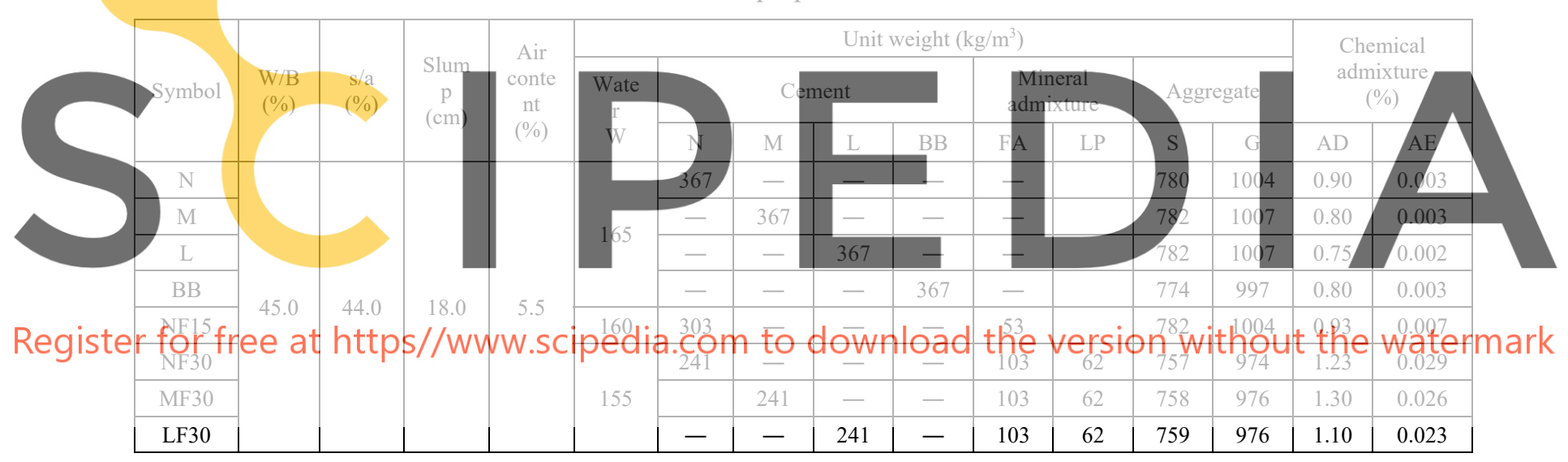

Table 4. Test items and methods.

\begin{tabular}{|c|c|c|}
\hline Test item & Test method & Description \\
\hline Slump & JIS A 1101 & \multirow{4}{*}{$\begin{array}{lrr}\text { Tested } & 5 & \text { minutes } \\
\text { and } 60 & \text { minutes } \\
\text { after } & \text { being } & \text { mixed } \\
\text { up } & & \end{array}$} \\
\hline Air content & JIS A 1128 & \\
\hline Mass of unit volume & JIS A 1116 & \\
\hline Concrete temperature & JIS A 1156 & \\
\hline Compressive strength & JIS A 1108 & \multirow{3}{*}{$\begin{array}{l}\text { Tested at the age of } \\
7 \text { days, } 28 \text { days, } \\
56 \text { days, } 91 \text { days, } \\
182 \text { days, } \quad 364 \text { days }\end{array}$} \\
\hline Static Young's modulus & JIS A 1149 & \\
\hline Dynamic Young's modulus & JIS A 1127 & \\
\hline
\end{tabular}

Table 5. Test results of fresh concrete.

\begin{tabular}{|c|c|c|c|c|c|c|c|c|}
\hline \multirow{2}{*}{$\begin{array}{c}\text { Sym } \\
\text {-bol }\end{array}$} & \multicolumn{2}{|c|}{$\begin{array}{c}\text { Slump } \\
(\mathrm{cm})\end{array}$} & \multicolumn{2}{c|}{$\begin{array}{c}\text { Air content } \\
(\%)\end{array}$} & \multicolumn{2}{c|}{$\begin{array}{c}\text { Mass of unit } \\
\text { volume } \\
\left(\mathrm{kg} / \mathrm{m}^{3}\right)\end{array}$} & \multicolumn{2}{c|}{$\begin{array}{c}\text { Concrete } \\
\text { temperature } \\
\left({ }^{\circ} \mathrm{C}\right)\end{array}$} \\
\cline { 2 - 9 } & $\begin{array}{c}5 \\
\text { min }\end{array}$ & $\begin{array}{c}60 \\
\mathrm{~min}\end{array}$ & $\begin{array}{c}5 \\
\mathrm{~min}\end{array}$ & $\begin{array}{c}60 \\
\mathrm{~min}\end{array}$ & $\begin{array}{c}5 \\
\mathrm{~min}\end{array}$ & $\begin{array}{c}60 \\
\mathrm{~min}\end{array}$ & $\begin{array}{c}5 \\
\mathrm{~min}\end{array}$ & $\begin{array}{c}60 \\
\mathrm{~min}\end{array}$ \\
\hline $\mathrm{N}$ & 20.0 & 19.5 & 6.1 & 5.7 & 2324 & 2319 & 21 & 21 \\
\hline M & 18.5 & 20.0 & 6.5 & 6.7 & 2303 & 2296 & 19 & 19 \\
\hline L & 21.5 & 20.5 & 6.3 & 6.1 & 2312 & 2309 & 19 & 19 \\
\hline BB & 19.5 & 20.0 & 4.9 & 5.3 & 2333 & 2322 & 19 & 19 \\
\hline NF15 & 18.0 & 18.0 & 5.3 & 5.4 & 2325 & 2315 & 21 & 21 \\
\hline NF30 & 18.0 & 17.5 & 7.1 & 6.5 & 2255 & 2277 & 21 & 21 \\
\hline MF30 & 17.0 & 20.0 & 7.0 & 6.5 & 2263 & 2279 & 21 & 21 \\
\hline LF30 & 19.5 & 18.5 & 8.5 & 6.1 & 2282 & 2294 & 22 & 21 \\
\hline
\end{tabular}




\subsection{Relationship between Age and Compressive Strength}

Figure 1 shows the relationship between age and compressive strength for each mix proportion. The strength at the age of 7 days of the mix proportions using only Portland cement without FA increased in the order of $\mathrm{N}>\mathrm{M}>\mathrm{L}$, and the higher the curing temperature, the faster the development of strength. However, at a high curing temperature of $30^{\circ} \mathrm{C}$, their increase of strength tended to slow down in an earlier stage: $\mathrm{N}$ peaked after age 28 days; $\mathrm{M}$ after 56 days; L after 91 days. On the other hand, it was observed that all the mix proportions with FA replacement for cement did not reach the peak and still continued to develop their strengths. The substitution of FA for cement demonstrates a high effect on strength increase.

The compressive strength of $\mathrm{BB}$ at the age of 7 days varied largely due to curing temperature, and at the temperature of $30^{\circ} \mathrm{C}$, was equivalent to $\mathrm{N}$, and at $5^{\circ} \mathrm{C}$ equivalent to $\mathrm{M}$, with a large difference from the mix with Portland cement without FA. At the curing temperature of $30^{\circ} \mathrm{C}$, the growth in strength of BB slowed down after 56 days of age.

On the other hand, the strength for mix proportions with FA developed in the order of NF15> NF30 $>$ MF30 $>$ LF30, and grew for a long period regardless of differences in binder type and curing temperature.

\subsection{Relationship between Temperature Adjusted Concrete Age and Compressive} Strength

The strength development of concrete is closely related with the maturity (time considering temperature ingredient) (Fuminori et al., 1991), and this tendency is more prondunced for the
case of a mix proportion using FA (pozzolan material). We studied on the relationship
between temperature-adjusted concrete age (te) and compressive strength
1990) which are shown in Equation (1); maturity law. $t_{e}=\sum^{n} \Delta t_{i} \cdot \exp \left[13.65-\frac{4000}{273+T\left(\Delta t_{i}\right)}\right]$

Register for free at https//www.scipecilia.com to download the version without the watermark
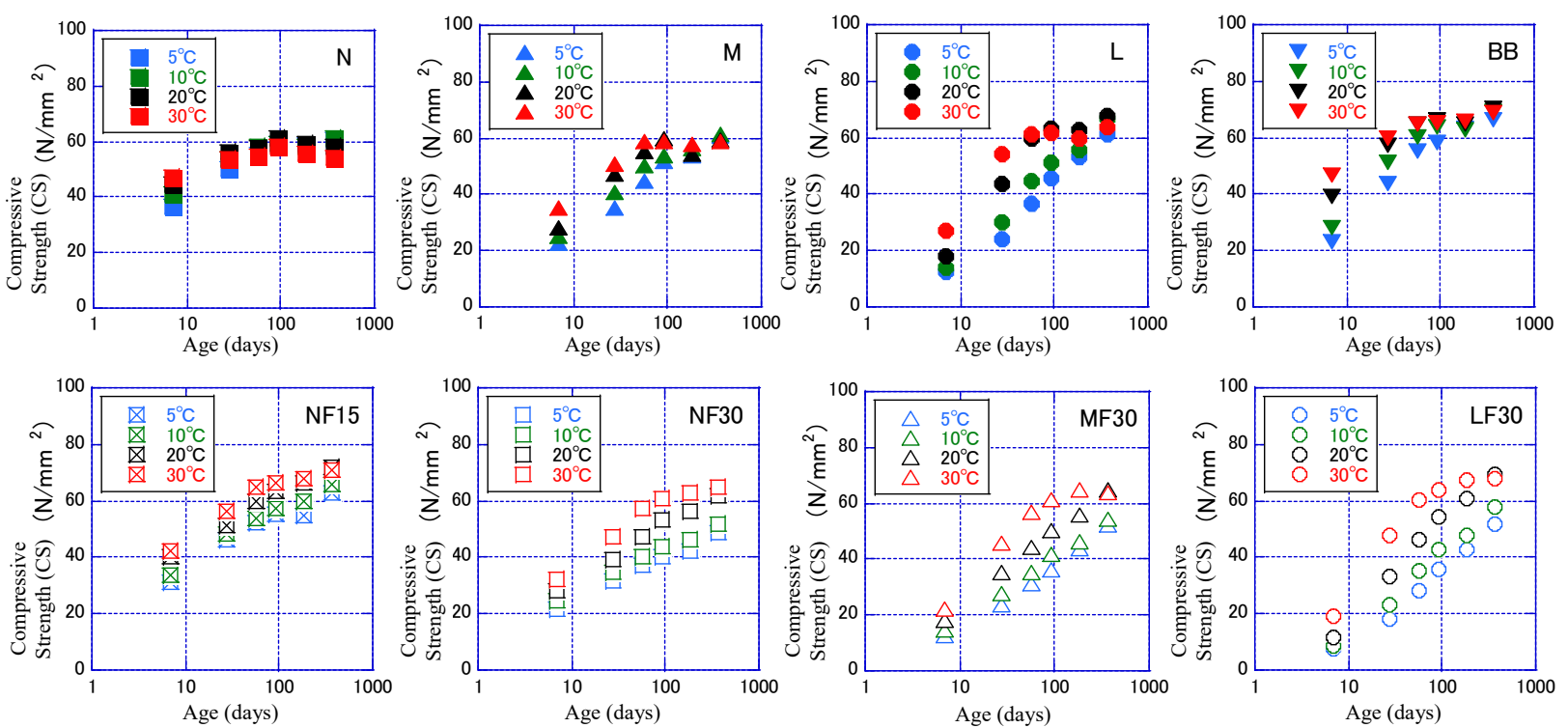

Figure 1. Relationship between concrete age and compressive strength in each mix. 
Figure 2 shows the results of the relationship between temperature-adjusted concrete age and compressive strength for each mix proportion. The results of the regression analysis using Equation (2) are shown in Table 6 and Figure 2.

$$
f\left(t_{e}\right)=a \cdot \log _{10} t_{e}+b
$$

For N, M, L and BB, the data were regressed in the range with high linearity. "a" and "b" are regression coefficients obtained from experimental results.

Figure 2 indicates that the relationship between temperature adjusted concrete age and compressive strength for the mix proportions using FA keeps linearity for one year, while the relationship not using FA has limited linearity up to 91 days, from which we learn that strength development by FA continues for a long span of time. In the case of N without FA, the long term strength peaks at $60 \mathrm{~N} / \mathrm{mm}^{2}$, while NF15 with $15 \%$ of cement replaced by FA still keeps increasing its strength even at about $80 \mathrm{~N} / \mathrm{mm}^{2}$, and NF15 with $30 \%$ replaced by FA does not peak even at $65 \mathrm{~N} / \mathrm{mm}^{2}$. In the case of $\mathrm{N}$, it was discovered that the effect of strength increase was greatly enhanced by about $15 \%$ replacement of cement by FA.
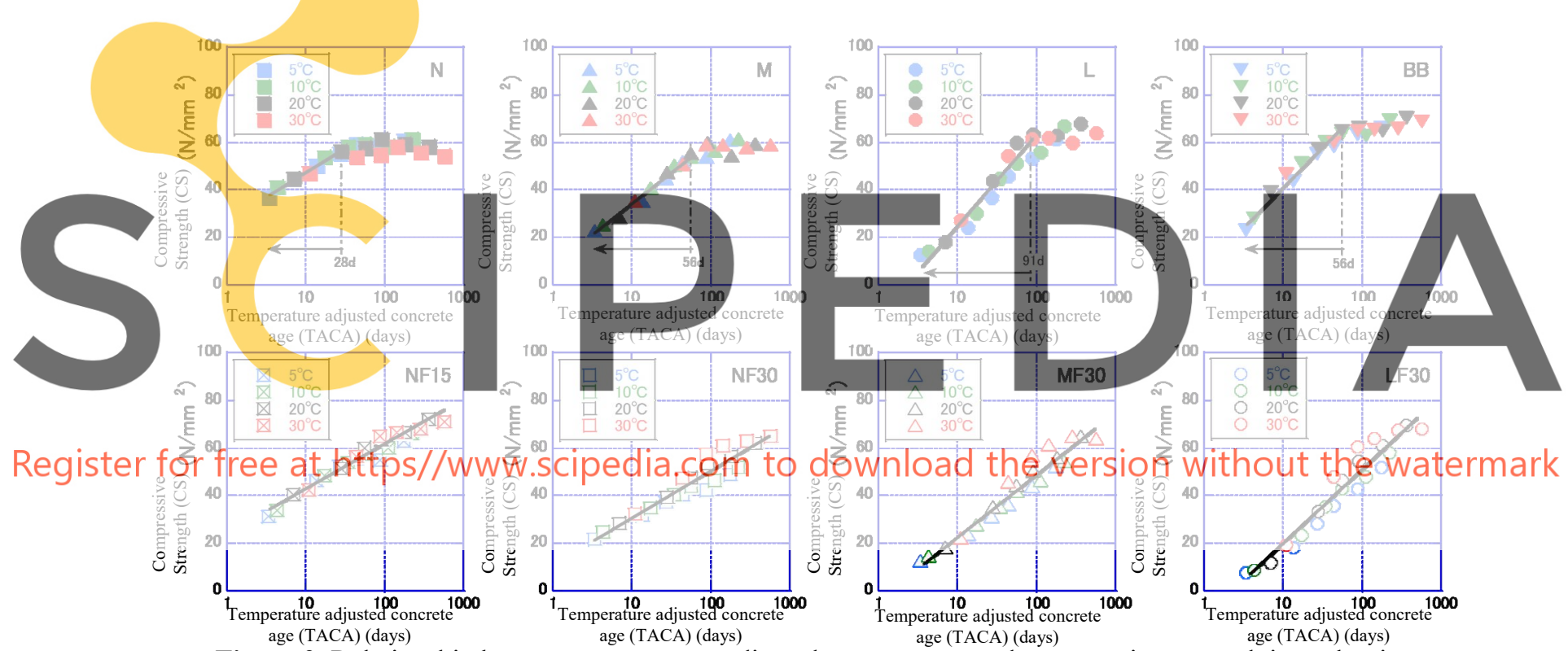

Figure 2. Relationship between temperature adjusted concrete age and compressive strength in each mix.

Table 6. Results of regression analysis for temperature adjusted concrete age and compression strength.

\begin{tabular}{|c|c|c|c|c|}
\hline \multirow[t]{2}{*}{ Symbol } & \multicolumn{2}{|c|}{$\begin{array}{l}\text { Regression } \\
\text { coefficient }\end{array}$} & \multirow{2}{*}{$\begin{array}{c}\text { Correlation } \\
\text { coefficient } \\
\mathrm{R}\end{array}$} & \multirow[t]{2}{*}{ Regression interval } \\
\hline & $\mathrm{a}$ & $\mathrm{b}$ & & \\
\hline $\mathrm{N}$ & 20.1 & 27.4 & 0.989 & $\begin{array}{l}\text { Up to Temperature } \\
\text { Adjusted Concrete Age } \\
\text { (TACA) } 28 \text { days }\end{array}$ \\
\hline $\mathrm{M}$ & 26.9 & 7.2 & 0.994 & Up to TACA 56 days \\
\hline $\mathrm{L}$ & 36.3 & -10.9 & 0.972 & Up to TACA 91 days \\
\hline $\mathrm{BB}$ & 31.9 & 9.5 & 0.983 & Up to TACA 56 days \\
\hline NF15 & 18.1 & 24.8 & 0.976 & Up to TACA 364 days \\
\hline NF30 & 19.5 & 11.2 & 0.952 & Up to TACA 364 days \\
\hline MF30 & 26.1 & -3.1 & 0.971 & Up to TACA 364 days \\
\hline LF30 & 31.5 & -12.5 & 0.967 & Up to TACA 364 days \\
\hline
\end{tabular}

Table 7. Results of regression analysis for temperature adjusted concrete age and static Young's modulus.

\begin{tabular}{|c|c|c|c|c|}
\hline \multirow[t]{2}{*}{ Symbol } & \multicolumn{2}{|c|}{$\begin{array}{l}\text { Regression } \\
\text { coefficient }\end{array}$} & \multirow{2}{*}{$\begin{array}{c}\text { Correlation } \\
\text { coefficient } \\
\mathrm{R} \\
\end{array}$} & \multirow[t]{2}{*}{ Regression interval } \\
\hline & $\mathrm{a}$ & $\mathrm{b}$ & & \\
\hline $\mathrm{N}$ & 5.61 & 35.1 & 0.964 & $\begin{array}{lr}\text { up to } & \text { Temperature } \\
\text { Adjusted } & \text { Concrete } \\
\text { Age (TACA) } 28 \text { days }\end{array}$ \\
\hline $\mathrm{M}$ & 6.70 & 29.9 & 0.990 & up to TACA 56 days \\
\hline $\mathrm{L}$ & 9.69 & 24.9 & 0.976 & up to TACA 91 days \\
\hline $\mathrm{BB}$ & 7.34 & 32.0 & 0.972 & up to TACA 56 days \\
\hline NF15 & 4.02 & 36.0 & 0.964 & up to TACA 364 days \\
\hline NF30 & 4.61 & 31.0 & 0.971 & up to TACA 364 days \\
\hline MF30 & 6.60 & 26.4 & 0.974 & up to TACA 364 days \\
\hline LF30 & 8.66 & 22.8 & 0.951 & up to TACA 364 days \\
\hline
\end{tabular}


Table- 6 shows the list of calculation results of regression coefficients "a" and "b". The larger the regression coefficient " $a$ ", the faster the increase in long-term strength, and the regression coefficient " $b$ " represents the initial strength. The regression coefficients "a" for the mixes using FA respectively are close to those of Portland cement as the base material (87 $\sim 97 \%$ to each cement). As is the case with the ranking of "a" of base cement ( $>>M>N)$, the ranking of the mix proportions using FA was in the order of LF30 $>$ MF30 $>$ NF30 $>$ NF15, and the regression coefficient "a" for BB was between that of $\mathrm{M}$ and $\mathrm{L}$.

On the other hand, it was found from the ranking of regression coefficients " $b$ " that the initial strengths of mix proportions are ranked in the order of $N>N F 15>N F 30>B B>M>$ MF30 $>$ L $>$ LF30. The initial strength of the mix proportion using FA decreases as the initial strength of the base cement decreases and as the FA replacement rate increases.

\subsection{Relationship Between Temperature Adjusted Concrete Age and Static Young's}

\section{Modulus}

Figure 3 shows the relationship between temperature adjusted concrete age and static Young's modulus, and Table 7 shows the results of linear regression analysis. The range of regression analysis was the same as that of the compression strength regression analysis in Section 3.3.

The static Young's modulus tended to develop in the same manner as the compressive strength. In other words, in the concretes without FA, the regression coefficient "a" was ranked in the order of $\mathrm{L}>\mathrm{BB}>\mathrm{M}>\mathrm{N}$, and in the concretes using FA, in the order of LF30>
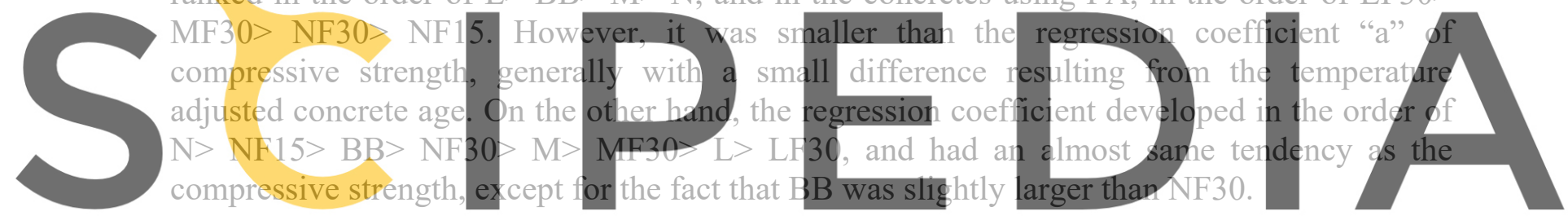

Register fok free at https//www scipedia.com to download the versionsowithout the watermark
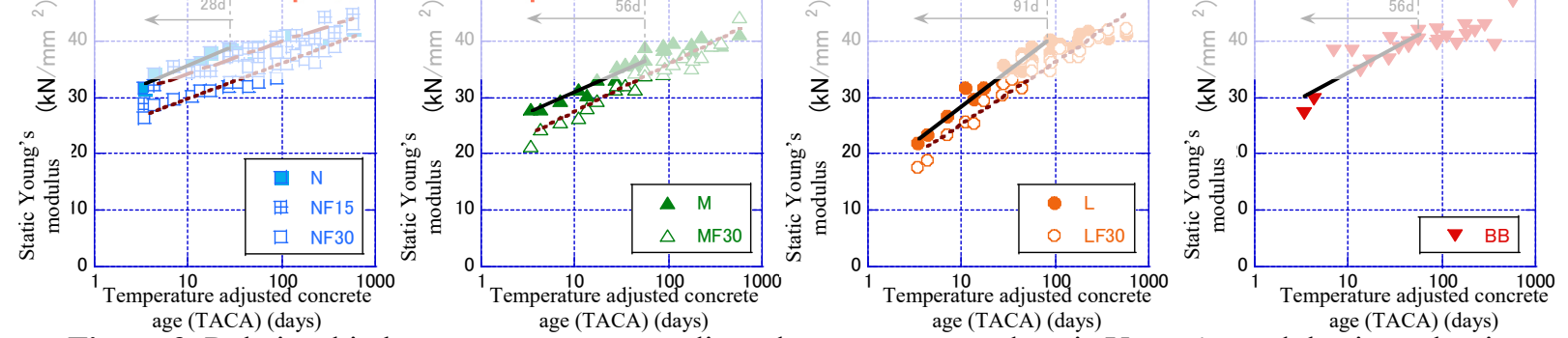

Figure 3. Relationship between temperature adjusted concrete age and static Young's modulus in each mix
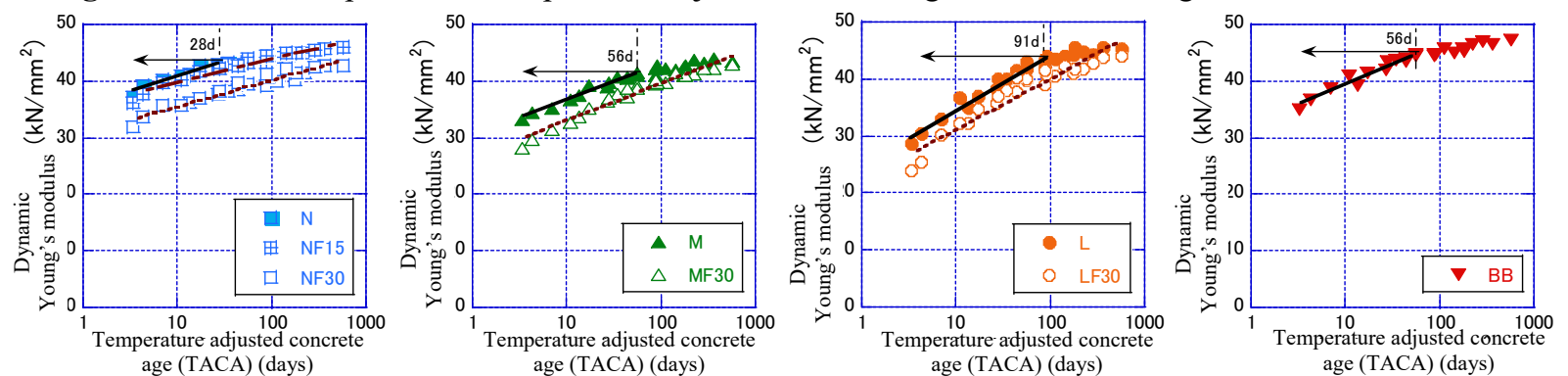

Figure 4. Relationship between temperature adjusted concrete age and dynamic Young's modulus in each mix. 


\subsection{Relationship Between Temperature Adjusted Concrete Age and Dynamic Young's Modulus}

Figure 4 shows the relationship between temperature adjusted concrete age and dynamic Young's modulus, and Table 8 the results of linear regression analysis. The range of regression analysis was the same as in Section 3.3.

From the difference in regression coefficient of "a", it was confirmed that the dynamic Young's modulus developed earlier than the compressive strength and static Young's modulus and tended to level off earlier with the age. The magnitude relationship of the regression coefficients " $a$ " and " $b$ " demonstrated the same tendency as in the static Young's modulus.

\subsection{Relationship Between Compressive Strength and Young's Modulus}

Figure 5 shows the relationship between compressive strength and static Young's modulus, Figure 6 shows the relationship between compressive strength and dynamic Young's modulus, and Figure 7 shows the relationship between static Young's modulus and dynamic Young's modulus.

Regardless of the types of binder or the use of FA, the relationship between compressive strength and static Young's modulus and the relationship between compressive strength and dynamic Young's modulus were constant. Moreover, the dynamic Young's modulus tended to fluctuate less than the static modulus.

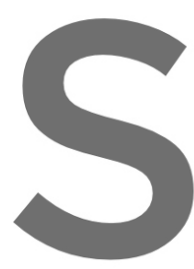

The dynamic generally given by the vibration at which the s: resonant vibration. represents a status where alnost no load works, it tends to grow larger than the

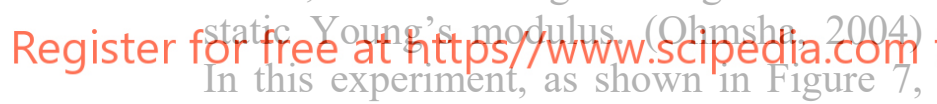
the dynamic Young's modulus was larger than the static Young's modulus. This trend was more noticeable at young ages.

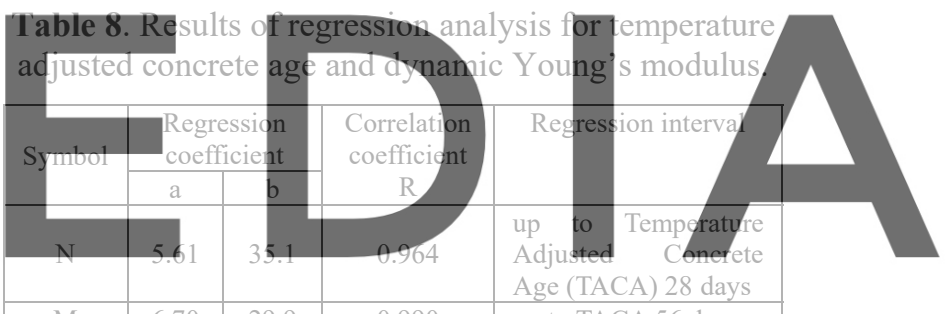

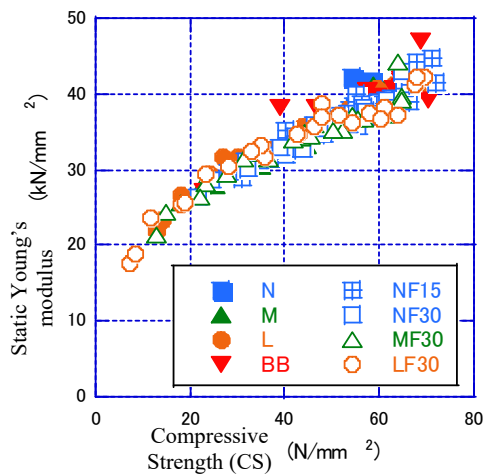

Figure 5. Relationship between compressive strength and static Young's modulus.

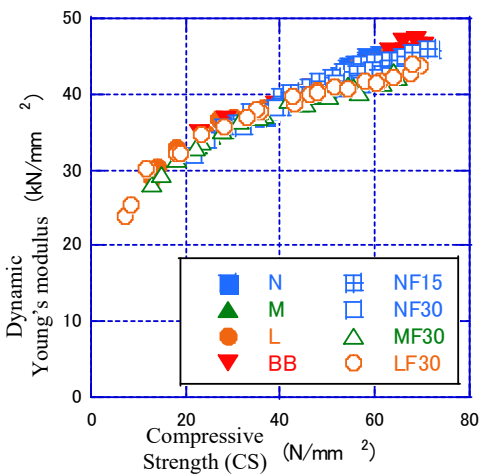

Figure 6. Relationship between compressive strength and dynamic Young's modulus.

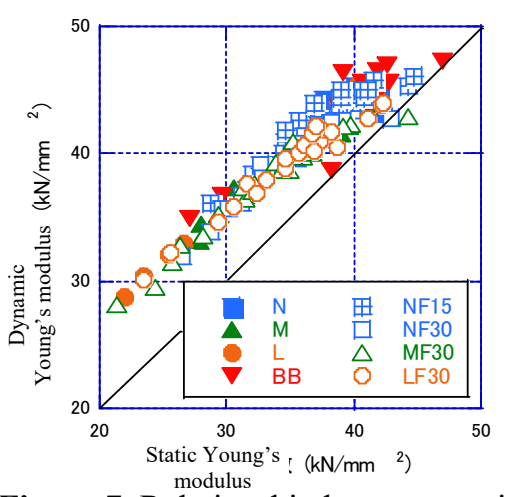

Figure 7. Relationship between static Young's modulus and dynamic Young's modulus. 


\section{Conclusion}

The following two types of concrete, one using three Portland cements (N, M, L) with no FA and the other using the same cements but partially replaced by FA, at a water-binder ratio of $45 \%$ and cured at different curing temperatures, were comparatively studied in terms of the compressive strength up to one year of age as well as of static and dynamic Young's moduli, including an experiment using blast furnace cement B (BB). We compared the data of these specimens to determine their relationship with temperature adjusted concrete age. The obtained results obtained are as follows:

(1) The mix proportion with $30 \%$ of cement replaced by FA, despite increasing AE agent, recorded more than $0.5 \%$ decrease in air content which is presumably due to the effect of FA' s unburned carbon.

(2) In the mix proportions (blending) of $\mathrm{N}, \mathrm{M}, \mathrm{L}$ and $\mathrm{BB}$, the higher the temperature, the faster the strength develoned. However, strength increase slowed down early and reached a peak. On the other hand, the mix proportions (blending) using FA steadily developed longterm strength regardless of the difference in binder and curing temperature, exceeding the long-term strengths of $\mathrm{N}$ and $\mathrm{M}$. Especially N15, which is a mix proportion of $\mathrm{N}$ with $15 \%$ FA replacement, did not peak even at about $80 \mathrm{~N} / \mathrm{mm}^{2}$ of compressive strength which is 1.3 times N's peak of $60 \mathrm{~N} / \mathrm{mm}^{2}$, and we learned that FA substitution has a high impact on the compressive strength.

(3) In the mix proportions (blending) using N, M, L, and BB, it was shown that the strength increased highly correlated with the temperature adjusted concrete age (in logarithn) up to the moment its proportions (blending) close correlation with th (4) It was found tha
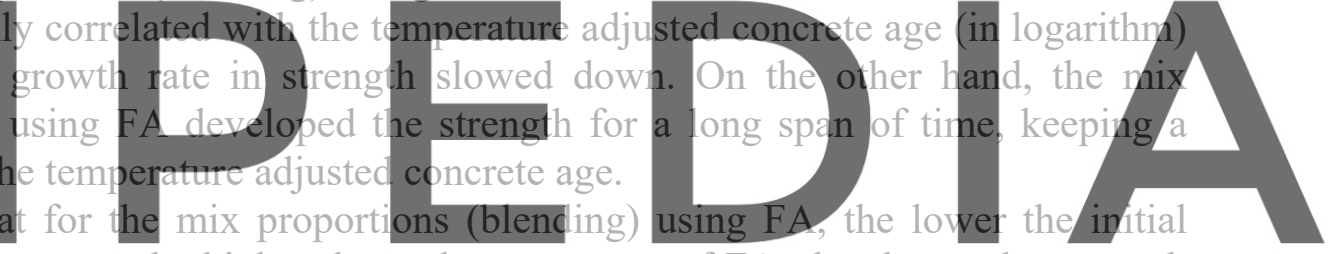

strength of the base cement or the higher the replacement rate of FA, the slower the strength

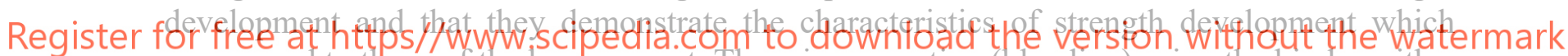
correspond to those of the base cement. The mix proportion (blending) using the binder with a slower initial strength development tended to result in the larger strength.

(5) Regardless of the use of FA in the mix, the relationship between compressive strength and static Young's modulus and the relationship between compressive strength and dynamic Young's modulus were constant. The dynamic Young's modulus demonstrated a larger value than the static Young's modulus, and this trend was more conspicuous at young ages.

\section{ORCID}

Takafumi Noguchi: https://orcid.org/0000-0001-6115-2292

\section{References}

CEB-FIP Model Code 1990 (1990). Comite Euro-international du Beton

Fuminori Tomosawa. and Sakae Ushijima (1991). Development and application of recent cumulative temperature systems, Cement/Concrete, No.527, pp.66-75

Ohmsha, Ltd (2004). Relationship between static Young's modulus and dynamic Young's modulus, by Kazusuke Kobayashi, supervising editor

Takafumi Noguchi (2014). Issues and perspective on the active use of additives for architecture, Concrete Engineering, Vol.52, No.5, pp.368-372 